\title{
Short communication: Effect of replacing corn with beet pulp in a high concentrate diet fed to weaned Holstein calves on diet digestibility and growth
}

\author{
T. S. Dennis, ${ }^{* 1}$ F. X. Suarez-Mena, ${ }^{*}$ T. M. Hill, ${ }^{*}$ J. D. Quigley, ${ }^{*}$ R. L. Schlotterbeck, ${ }^{*}$ and G. J. Lascano† \\ *Nurture Research Center, Provimi, Brookville, OH 45309 \\ †Animal and Veterinary Sciences, Clemson University, Clemson, SC 29634
}

\begin{abstract}
Using soluble fiber sources in starter and grower feeds for dairy calves less than 4 mo of age is common to reduce costs compared with including traditional cereal grains. Beet pulp (BP) contains relatively high concentrations of pectin compared with other fibrous feed ingredients and has been shown to be an acceptable replacement for corn in adult cow diets. However, limited information is available on BP digestibility and growth performance for young calves fed diets with BP. In this study, 48 male Holstein calves (59 \pm 2 d of age, $77 \pm$ $2.2 \mathrm{~kg}$ of initial body weight) were fed $95 \%$ concentrate, $5 \%$ chopped grass hay diets in groups with 4 calves/pen for $56 \mathrm{~d}$. Pens were randomly assigned to 1 of 3 dietary treatments containing 0,15 , or $30 \% \mathrm{BP}$ on an as-fed basis. Body weights, hip widths, and body condition scores were assessed at 56 (start of trial), 84, and 112 $\mathrm{d}$ of age. Dry matter intakes and refusals were recorded daily by pen. Digestion coefficients $(\mathrm{dC})$ of the diets and microbial protein flows were estimated when calves were approximately $84 \mathrm{~d}$ of age. Fecal samples were collected daily from pen floors over a 7-d period, and urine samples were collected from 2 calves/pen over a 2 -d period and analyzed for purine derivatives. Calf average daily gain and hip width change decreased linearly (from 1.09 to $1.04 \mathrm{~kg} / \mathrm{d}$ and 5.4 to $4.8 \mathrm{~cm}$ over $56 \mathrm{~d}$, respectively) with increasing BP. Dry matter, organic matter (from 79.7 to $75.6 \%$ ), crude protein (75.7 to $70.1 \%$ ), and starch (97.1 to $93.1 \%$ ) dC decreased with increasing inclusion rates of BP. Conversely, neutral detergent fiber (from 47.1 to $52.7 \%$ ) and acid detergent fiber (44.1 to $53.0 \%$ ) dC increased with increasing BP. Estimates of urine output and microbial protein flow using purine derivatives did not differ among treatments. Under the conditions of this study, BP reduced
\end{abstract}

Received June 5, 2017.

Accepted August 27, 2017.

${ }^{1}$ Corresponding author: tdennis@provimi-na.com growth largely by reducing diet digestibility in dairy calves from 56 to $112 \mathrm{~d}$ of age.

Key words: weaned calf, soluble fiber, digestibility, microbial protein

\section{Short Communication}

Starter and grower feeds formulated for dairy calves under 4 mo of age often include high amounts of fibrous by-product feeds to reduce costs. However, supplying fiber using wheat middlings, soybean hulls, distillers dried grains, or other fiber sources does not support similar growth in BW and frame compared with feeding lower-fiber, higher-starch feeds (Hill et al., 2010, 2016). As the concentration of structural carbohydrates increases in the diet of calves up to approximately 4 mo of age, ADG and structural growth frequently decline (Hill et al., 2010). Using either soybean hulls or wheat middlings to replace corn reduced digestibility, ADG, and hip width change in calves from 2 to 4 mo of age fed high-concentrate diets (Hill et al., 2016). Fiber sources are not as digestible in nonruminant animals, and high-fiber ingredients reduce growth even at low inclusion rates (Fahey et al., 1990; Zervas and Zijlstra, 2002). Although some fiber appears necessary (Hill et al., 2010; Castells et al., 2013), moderate to excessive amounts can reduce calf growth (Hill et al., 2010; Suarez-Mena et al., 2016). Discrepancies seem to suggest that excessive forage fiber may reduce intake, whereas added fiber from concentrates does not appear to have a negative effect on intake.

In mature dairy cows, substituting high-moisture corn with beet pulp (BP) increased total-tract digestion of OM and FCM yield, and shifted the site of starch digestion post-ruminally (Voelker and Allen, 2003a,b,c), while maintaining ruminal microbial efficiency and protein synthesis (Borucki Castro et al., 2008). Murdock and Wallenius (1980) reported no differences in BW gain of 0- to 3-mo-old calves when feeding a diet with $32 \%$ alfalfa meal, $17 \%$ cottonseed hulls, and $34 \%$ BP. Maktabi et al. (2016) reported improved ADG in calves 
up to 7 wk of age when adding $10 \%$ (vs. $0 \%$ ) BP to a starter but reported no differences in ADG to $10 \mathrm{wk}$ of age, structural growth to 7 and 10 wk of age, or digestibility among 0,10 , and $20 \%$ BP diets. Beet pulp is high in pectin, a type of soluble fiber that can be extensively used by ruminal microbes for growth compared with structural fiber in mature ruminants (Van Soest, 1987). Pectin content is greater in BP compared with other high-fiber concentrate sources $(23.3 \%$ of $\mathrm{DM}$ in BP vs. $8.8 \%$ of DM in soybean hulls; NRC, 2001) recently examined in high-concentrate diets for calves (Hill et al., 2010, 2016). These results suggest that BP could be a more viable replacement for corn in calf starter concentrates. Therefore, our hypothesis was that replacing corn with $\mathrm{BP}$ would result in similar digestion and growth in weaned dairy calves from 2 to 4 mo of age.

Calves were cared for by acceptable practices as described in the Guide for the Care and Use of Agricultural Animals in Research and Teaching (FASS, 2010). In the current study, 48 male weaned Holstein calves initially $59 \pm 2$ d of age from a single dairy farm were fed $95 \%$ starter concentrate, $5 \%$ chopped grass hay diets. Calves had been weaned for $14 \mathrm{~d}$ before starting the study. The preweaning diet for all calves was a $25 \% \mathrm{CP}, 18 \%$ fat milk replacer (DM basis) fed at $0.66 \mathrm{~kg} / \mathrm{d}$ from $\mathrm{d}$ 0 to 39 and $0.33 \mathrm{~kg} / \mathrm{d}$ from d 40 to 42 . All calves were fed a textured starter $(21.4 \% \mathrm{CP}$ and $41.6 \%$ starch on a DM basis) with $37 \%$ whole corn, $35 \%$ protein/ mineral pellet, $25 \%$ whole oats, and $3 \%$ liquid molasses from d 0 to 56 . Treatment grower concentrate formulas contained 0,15 , or $30 \% \mathrm{BP}$, replacing predominantly rolled corn (Table 1). The diets were textured and fed for ad libitum intake with free-choice water. Each treatment was randomly assigned to 16 calves housed in 4 pens ( 4 calves/pen). The pens where calves were housed had $6.5 \mathrm{~m}^{2}$ of outside pen space and $1.4 \mathrm{~m}^{2}$ of inside pen space per calf. Inside pen space was bedded with straw and there was no added heat. Calves were weighed and scored for body condition, and hip widths were measured at 0,28 , and $56 \mathrm{~d}$. Body condition score was evaluated on a 5-point system ( 1 being thin and 5 being obese; modified from Wildman et al., 1982, with the primary focus being to palpate the transverse processes of the backbone). One experienced technician assessed BCS and was blind to the experimental treatments. Fecal samples were collected twice daily from approximately 77 to $84 \mathrm{~d}$ of age from the pen floors (random from all areas of pen), with care taken not to sample soil or bedding, and composited by pen for each collection period. Acid insoluble ash (Van Keulen and Young, 1977) was used as an internal marker in feeds and fecal samples to estimate diet and nutrient digestibility. Urine spot samples were collected from 2 calves per pen over $2 \mathrm{~d}$ to estimate microbial protein flow using purine derivatives (Terré et al., 2006). Calves were restrained using a chute and samples were collected as calves spontaneously eliminated into a $50-\mathrm{mL}$ container. Urine samples were unacidified and frozen immediately after collection (stored at $-20^{\circ} \mathrm{C}$ ) by calf and day. The trial was conducted from February 3 to March 30, 2016. The average temperature during the trial was $4^{\circ} \mathrm{C}$ with a range from -17 to $23^{\circ} \mathrm{C}$. The average relative humidity was $80 \%$ with a range from 28 to $100 \%$.

Composites of feeds (samples taken from every other bag of starter and every bale of hay), refused feed, and feces were analyzed as described by Hill et al. (2016). Nutrient analysis of the refused feed for each week and pen resembled the feed offered. In addition, pectin was estimated using content of galacturonic acid after lipid extraction following procedures detailed in Hatfield and Weimer (1995) with ammonium oxalate extraction followed by colorimetric methodology (Van Soest et al., 1991). Pectin from citrus peel was used as a standard (Sigma-Aldrich, St. Louis, MO) with a galacturonic acid concentration of $78.7 \%$ and a reported pectin concentration of $91.5 \%$; therefore, a conversion factor of $86.0 \%$ expressed as galacturonic acid was used to calculate pectin concentration. Neutral detergent soluble fiber (NDSF) was measured as specified by Hall et al. (1999) with a previous lipid extraction and modifications related to neutral detergent residue and neutral detergent residue $\mathrm{CP}$ procedures adapted for the Ankom ${ }^{200}$ (Ankom Technology, Macedon, NY), and starch was analyzed using a modified procedure reported by Zanton and Heinrichs (2009). Urine samples were diluted with distilled water (dilution factor 1:10), and analyzed for uric acid (Cat No. 1045-225, Stanbio Laboratory, Boerne, TX) and allantoin (Chen and Gomes, 1992). Urine volumes were estimated as BW $\times 26.8 /$ creatinine concentration $(\mathrm{mg} / \mathrm{L}$; Valadares et al., 1999; Lascano and Heinrichs, 2011) from spot urine samples and used to calculate microbial protein flow. Urinary purine derivative (allantoin and uric acid) excretion was used to estimate duodenal flow of microbial protein (Chen and Gomes, 1992). Feed intake, BW, frame growth, and digestibility data were analyzed by 28 -d periods as a completely randomized design with repeated measures when applicable using the PROC MIXED procedure in SAS (version 9.2; SAS Institute Inc., Cary, NC). Calf BCS was analyzed using a Kruskal-Wallis test with PROC NPAR1WAY in SAS. An auto-regressive type 1 covariance matrix was used, as determined using Akaike's information criterion. No covariates were applied and means were evaluated using orthogonal polynomial contrasts for linear and quadratic responses. Pen was the experimental unit (n 
Table 1. Analyzed nutrient composition of diets containing 0,15 , or $30 \%$ beet pulp

\begin{tabular}{|c|c|c|c|c|}
\hline Item & $0 \%$ & $15 \%$ & $30 \%$ & Hay \\
\hline \multicolumn{5}{|l|}{ Ingredient, $\%$ as-fed } \\
\hline Beet pulp & 0.00 & 15.00 & 30.00 & - \\
\hline Corn, rolled & 30.31 & 15.89 & 1.47 & - \\
\hline Soybean meal & 18.10 & 17.68 & 17.27 & - \\
\hline Wheat middlings & 7.50 & 7.50 & 7.50 & - \\
\hline Oats, whole ${ }^{1}$ & 20.00 & 20.00 & 20.00 & - \\
\hline Corn, whole ${ }^{1}$ & 17.00 & 17.00 & 17.00 & - \\
\hline Molasses $^{1}$ & 3.00 & 3.00 & 3.00 & - \\
\hline Calcium carbonate & 1.13 & 0.86 & 0.58 & - \\
\hline Mineral and vitamin premix & 0.75 & 0.75 & 0.75 & - \\
\hline Monocalcium phosphate & 0.67 & 0.78 & 0.89 & - \\
\hline Salt & 0.60 & 0.60 & 0.60 & - \\
\hline Animal fat & 0.60 & 0.60 & 0.60 & - \\
\hline Pellet binder & 0.30 & 0.30 & 0.30 & - \\
\hline Decoquinate $6 \%$ & 0.04 & 0.04 & 0.04 & - \\
\hline \multicolumn{5}{|l|}{ Nutrient, $\%$ as-fed } \\
\hline $\mathrm{DM}$ & 87.1 & 86.9 & 87.3 & 86.1 \\
\hline \multicolumn{5}{|l|}{ Nutrient, \% of DM } \\
\hline $\mathrm{CP}$ & 18.2 & 18.3 & 18.4 & 9.6 \\
\hline $\mathrm{ADF}$ & 7.8 & 11.1 & 14.8 & 44.2 \\
\hline $\mathrm{NDF}$ & 16.4 & 20.5 & 23.3 & 67.4 \\
\hline Fat & 4.1 & 3.9 & 3.3 & 1.6 \\
\hline Ash & 5.8 & 4.4 & 7.7 & 9.0 \\
\hline Starch & 43.5 & 34.9 & 25.7 & 1.7 \\
\hline Sugar & 5.3 & 7.0 & 9.6 & 11.6 \\
\hline Pectin $^{2}$ & 2.9 & 5.6 & 7.2 & 2.1 \\
\hline $\mathrm{NDSF}^{3}$ & 5.0 & 8.2 & 10.2 & 2.5 \\
\hline
\end{tabular}

${ }^{1}$ Ingredients not within pellet.

${ }^{2}$ Pectin $=$ galacturonic acid content $/ 0.86$.

${ }^{3}$ Neutral detergent soluble fiber.

$=12$ ) for all variables. Significance was determined at $P \leq 0.05$.

Initial measurements did not differ (Table 2). Calf ADG and hip width change decreased linearly $(P \leq$ $0.01)$ with increasing $\mathrm{BP}$, and final calf hip width decreased quadratically $(P<0.05)$ with increasing BP. Digestibility coefficients $(\mathbf{d C})$ of $\mathrm{DM}, \mathrm{OM}, \mathrm{CP}$, and starch decreased linearly $(P<0.05)$ with increasing BP (Table 3). Digestibility coefficients of NDF and ADF increased linearly $(P \leq 0.05)$ with increasing BP. Intake of calves during the week of estimating digestibility responded quadratically $(P<0.05)$ to the level of BP in the diet. However, we detected no differences in DM intake when expressed per unit of BW. Estimates of urine output and microbial protein flow did not differ among treatments.

Growth of calves appeared largely driven by diet $\mathrm{OM}$ $\mathrm{dC}$ : growth decreased as BP content increased because

Table 2. Performance of calves fed diets with 0,15 , or $30 \%$ beet pulp

\begin{tabular}{|c|c|c|c|c|c|c|}
\hline \multirow[b]{2}{*}{ Item } & \multirow[b]{2}{*}{$0 \%$} & \multirow[b]{2}{*}{$15 \%$} & \multirow[b]{2}{*}{$30 \%$} & \multirow[b]{2}{*}{ SEM } & \multicolumn{2}{|c|}{ Contrast $P$-value } \\
\hline & & & & & Linear & Quadratic \\
\hline Initial BW, $\mathrm{kg}$ & 78.5 & 76.7 & 76.7 & 2.24 & 0.59 & 0.75 \\
\hline Final BW, kg & 139.6 & 135.7 & 135.0 & 2.32 & 0.20 & 0.58 \\
\hline Initial hip width, $\mathrm{cm}$ & 21.7 & 21.0 & 21.3 & 0.19 & 0.15 & 0.08 \\
\hline Final hip width, cm & 27.1 & 26.1 & 26.1 & 0.15 & $<0.01$ & 0.03 \\
\hline Initial BCS ${ }^{1}$ & 2.4 & 2.4 & 2.5 & 0.05 & 0.48 & 0.68 \\
\hline Final BCS & 2.8 & 2.8 & 2.9 & 0.04 & 0.32 & 0.77 \\
\hline DMI, kg/d & 3.14 & 2.97 & 3.10 & 0.072 & 0.68 & 0.13 \\
\hline DMI, $\%$ of $\mathrm{BW}^{2}$ & 2.92 & 2.86 & 2.96 & 0.046 & 0.58 & 0.21 \\
\hline $\mathrm{ADG}, \mathrm{kg} / \mathrm{d}$ & 1.09 & 1.05 & 1.04 & 0.011 & 0.01 & 0.37 \\
\hline Feed efficiency, gain/feed & 0.35 & 0.35 & 0.34 & 0.008 & 0.38 & 0.40 \\
\hline Hip width change, cm & 5.4 & 5.1 & 4.8 & 0.08 & $<0.01$ & 0.83 \\
\hline BCS change & 0.4 & 0.4 & 0.4 & 0.03 & 0.69 & 0.27 \\
\hline
\end{tabular}

${ }^{1}$ Body condition score on 1 to 5 scale (modified from Wildman et al., 1982).

${ }^{2}$ DMI divided by BW multiplied by 100 , based on pen averages. 
intake was unaffected. The lower $\mathrm{dC}$ observed in calves in the present experiment was similar to the lower $\mathrm{dC}$ of fibrous feeds including BP in dogs and pigs (Fahey et al., 1990; Zervas and Zijlstra, 2002). Beet pulp ADF and NDF appeared to be digested well as a fiber source, as reflected in the increasing $\mathrm{dC}$ of $\mathrm{ADF}$ and NDF with increasing BP in the diet. Similarly, fibrous concentrates (soybean hulls and wheat middlings) had greater $\mathrm{dC}$ for ADF and NDF than did high-starch diets based on corn (Hill et al., 2016), yet growth of calves fed diets with high fibrous concentrates was less than that with high corn diets. However, dC of ADF and NDF $(<54 \%)$ were still significantly lower than $\mathrm{dC}$ of starch $(>93 \%)$. A gradual transition to BP between 2 and 4 mo of age might have yielded better results, as was the case with diets containing high fibrous concentrates based on soybean hulls and wheat middlings (Hill et al., 2012). The similar estimates of microbial protein flow using purine derivatives and creatinine as a marker for urine volume must be viewed with caution because of their variable nature. These estimations for urine volume and microbial protein flow, although valuable (Terré et al., 2006), can be poor predictors of purine derivatives compared with total collection in intensive studies (Shingfield and Offer, 1998). If microbial protein flow was similar, this could suggest that inclusion of $15 \%$ or less BP might be considered in future research with calves. However, given the linear reduction in digestion of OM by replacing corn with BP in the current study, and previous reductions in digestion of OM with replacing corn with soybean hulls or wheat middlings (Hill et al., 2016), substituting starch with fibrous concentrate sources cannot be recommended for calves less than 4 mo of age. It is important to consider that the rumen microbial population is dynamic and still developing in calves before, during, and following weaning ( $\mathrm{Li}$ et al., 2012). Bacteria populations classified under the phyla Bacteroidetes (Prevotella and Butyrivibrio spp.) were shown to increase from 2 to 6 and from 6 to 24 mo of age in Israeli Holstein heifers (Jami et al., 2013). Bacteria classified under the genera Prevotella and Butyrivibrio are predominantly responsible for hydrolyzing pectin and other noncellulosic polysaccharides (Marounek and Dušková, 1999). Despite BP having been shown to be an acceptable replacement for corn as an energy source in mature cow diets, the rumen microbial profile in weaned calves is not likely diverse enough to utilize feeds with high amounts of pectin or soluble fiber. However, calves in the present experiment were transitioned to the treatment diets from a starter with no BP inclusion, which might have affected digestibility and growth. Additionally, potential differences in rumen volume after weaning could affect passage rate depending on diet composition. Castells et al. (2013) reported increased fractional rumen passage rate with decreasing empty rumen weight when oat hay was offered with pelleted starter to calves pre- and postweaning up to $70 \mathrm{~d}$ of age compared with calves fed only starter. This resulted in lesser mean total-tract retention time (18.8 vs. $28.4 \mathrm{~h}$ ), which corresponded to greater DM and NDF intakes for calves fed oat hay with starter compared with starter only (Castells et

Table 3. Nutrient digestibility, urine output, and estimated microbial protein flow by calves fed diets with 0 , 15 , or $30 \%$ beet pulp at $84 \mathrm{~d}$ of age

\begin{tabular}{|c|c|c|c|c|c|c|}
\hline \multirow[b]{2}{*}{ Item } & \multirow[b]{2}{*}{$0 \%$} & \multirow[b]{2}{*}{$15 \%$} & \multirow[b]{2}{*}{$30 \%$} & \multirow[b]{2}{*}{ SEM } & \multicolumn{2}{|c|}{ Contrast $P$-value } \\
\hline & & & & & Linear & Quadratic \\
\hline \multicolumn{7}{|l|}{ During fecal collection } \\
\hline $\mathrm{BW},{ }^{\mathrm{l}} \mathrm{kg}$ & 105.3 & 101.6 & 103.2 & 1.94 & 0.45 & 0.29 \\
\hline DMI, kg/d & 3.1 & 3.0 & 3.2 & 0.06 & 0.48 & 0.03 \\
\hline \multicolumn{7}{|l|}{ Digestibility, \% } \\
\hline $\mathrm{DM}$ & 78.2 & 75.5 & 73.9 & 0.59 & $<0.01$ & 0.49 \\
\hline $\mathrm{OM}$ & 79.7 & 78.0 & 75.6 & 0.67 & $<0.01$ & 0.72 \\
\hline $\mathrm{CP}$ & 75.7 & 72.9 & 70.1 & 1.34 & 0.02 & 0.98 \\
\hline $\mathrm{NDF}$ & 47.1 & 51.3 & 52.7 & 1.62 & 0.04 & 0.51 \\
\hline $\mathrm{ADF}$ & 44.1 & 48.6 & 53.0 & 1.99 & 0.01 & 0.96 \\
\hline Starch & 97.1 & 95.3 & 93.1 & 0.64 & $<0.01$ & 0.78 \\
\hline Fat & 76.9 & 76.4 & 72.7 & 2.17 & 0.20 & 0.56 \\
\hline \multicolumn{7}{|l|}{ During urine collection } \\
\hline $\mathrm{BW},{ }^{2} \mathrm{~kg}$ & 106.6 & 108.6 & 105.0 & 5.16 & 0.82 & 0.62 \\
\hline Urine output ${ }^{3} \mathrm{~L} / \mathrm{d}$ & 1.9 & 3.5 & 3.8 & 0.72 & 0.16 & 0.41 \\
\hline Microbial protein, ${ }^{4} \mathrm{~g} / \mathrm{d}$ & 131 & 156 & 161 & 27.4 & 0.42 & 0.74 \\
\hline
\end{tabular}


al., 2013). Although DM intake in the current study was similar among treatments, greater dietary NDF intake would be numerically greater with increasing BP inclusion, which could have increased fractional rumen passage rate, resulting in lesser total-tract $\mathrm{dC}$ of $\mathrm{OM}$. However, assessing the microbial profile or rumen passage rate of calves fed BP in this study was outside the scope of the original objectives, and future research should investigate how postweaning diets affect the evolution of the microbiome and rumen kinetics.

Increasing amounts of $\mathrm{BP}(0,15$, and $30 \%)$ largely replacing corn in high-concentrate diets of weaned dairy calves from 2 to 4 mo of age reduced ADG and structural growth largely through reducing diet digestibility by increasing dietary NDF and ADF content. These results are consistent with other results in calves fed high-concentrate diets and point to the importance of feeding young calves $(<4$ mo of age) diets with limited $\mathrm{NDF}$ and ADF content.

\section{ACKNOWLEDGMENTS}

This research was fully funded by Provimi, Brookville, Ohio.

\section{REFERENCES}

Borucki Castro, S. I., L. E. Phillip, H. Lapierre, P. W. Jardon, and R. Berthiaume. 2008. The relative merit of ruminal undegradable protein from soybean meal or soluble fiber from beet pulp to improve nitrogen utilization in dairy cows. J. Dairy Sci. 91:3947-3957.

Castells, L., A. Bach, A. Aris, and M. Terré. 2013. Effects of forage provision to young calves on rumen fermentation and development of the gastrointestinal tract. J. Dairy Sci. 96:5226-5236.

Chen, X. B., and M. J. Gomes. 1992. Estimation of microbial protein supply to sheep and cattle based on urinary excretion of purine derivatives: An overview of technical details. Rowett Research Institute, Aberdeen, UK.

Fahey, G. C. Jr., N. R. Merchen, J. E. Corbin, A. K. Hamilton, K. A. Serb, S. M. Lewis, and D. A. Hirakawa. 1990. Dietary fiber for dogs: 1. Effects of graded levels of dietary beet pulp on nutrient intake, digestiblility, metabolizable energy, and digesta mean retention time. J. Anim. Sci. 68:4221-4228.

FASS. 2010. Guide for the Care and Use of Agricultural Animals in Research and Teaching. 3rd ed. Fed. Anim. Sci. Soc., Savoy, IL.

Hall, M. B., W. H. Hoover, J. P. Jennings, and T. K. M. Webster. 1999. A method for partitioning neutral detergent-soluble carbohydrates. J. Sci. Food Agric. 79:2079-2086.

Hatfield, R. D., and P. J. Weimer. 1995. Degradation characteristics of isolated and in situ cell wall lucerne pectic polysaccharides by mixed ruminal microbes. J. Sci. Food Agric. 69:185-196.

Hill, T. M., H. G. Bateman II, J. M. Aldrich, and R. L. Schlotterbeck. 2010. Roughage amount, source, and processing for diets fed to weaned dairy calves. Prof. Anim. Sci. 26:181-187.

Hill, T. M., H. G. Bateman II, J. M. Aldrich, and R. L. Schlotterbeck. 2012. High starch coarse grain low fiber starters maximize growth of weaned dairy calves less than 4 months of age. Prof. Anim. Sci. $28: 325-331$.

Hill, T. M., J. D. Quigley, H. G. Bateman II, J. M. Aldrich, and R. L. Schlotterbeck. 2016. Source of carbohydrate and metabolizable lysine and methionine in the diet of recently weaned dairy calves on digestion and growth. J. Dairy Sci. 99:2788-2796.
Jami, E., A. Israel, A. Kotser, and I. Mizrahi. 2013. Exploring the bovine rumen bacterial community from birth to adulthood. ISME J. 7:1069-1079.

Lascano, G. J., and A. J. Heinrichs. 2011. Effects of feeding different levels of dietary fiber through the addition of corn stover on nutrient utilization of dairy heifers precision-fed high and low concentrate diets. J. Dairy Sci. 94:3025-3036.

Li, R. W., E. E. Connor, C. Li, R. L. Baldwin VI, and M. E. Sparks. 2012. Characterization of the rumen microbiota of pre-ruminant calves using metagenomic tools. Environ. Microbiol. 14:129-139.

Maktabi, H., E. Ghasemi, and M. Khorvash. 2016. Effects of substituting grain with forage or nonforage fiber source on growth performance, rumen fermentation, and chewing activity of dairy calves. Anim. Feed Sci. Technol. 221:70-78.

Marounek, M., and D. Dušková. 1999. Metabolism of pectin in rumen bacteria Butyrivibrio fibrisolvens and Prevotella ruminicola. Lett. Appl. Microbiol. 29:429-433.

Murdock, F. R., and R. W. Wallenius. 1980. Fiber sources for complete calf starter rations. J. Dairy Sci. 63:1869-1873.

NRC. 2001. Nutrient Requirements of Dairy Cattle. 7th rev. ed. National Academies Press, Washington, D.C.

Shingfield, K., and N. Offer. 1998. Evaluation of the spot urine sampling technique to assess urinary purine derivative excretion in lactating dairy cows. Anim. Sci. 66:557-568.

Suarez-Mena, F. X., T. S. Dennis, T. M. Hill, J. D. Quigley, and R. L. Schlotterbeck. 2016. Feeding 5\% grass hay or wheat straw with high starch, textured diets to weaned dairy calves between 8 and 16 weeks of age. J. Dairy Sci. 99(E-Suppl. 1):362. (Abstr.)

Terré, M., M. Devant, and A. Bach. 2006. Performance and nitrogen metabolism of calves fed conventionally or following an enhancedgrowth feeding program during the preweaning period. Livest. Sci. 105:109-119.

Valadares, R. F., G. A. Broderick, S. C. Valadares Filho, and M. K. Clayton. 1999. Effect of replacing alfalfa silage with high moisture corn on ruminal protein synthesis estimated from excretion of total purine derivatives. J. Dairy Sci. 82:2686-2696.

Van Keulen, J., and B. A. Young. 1977. Evaluation of acid-insoluble ash as a natural marker in ruminant digestibility studies. J. Anim. Sci. 44:282-287.

Van Soest, P. J. 1987. Nutritional Ecology of the Ruminant: Ruminant Metabolism, Nutritional Strategies, the Cellulolytic Fermentation and the Chemistry of Forages and Plant Fibers. Cornell University Press, Ithaca, NY

Van Soest, P. J., J. B. Robertson, and B. A. Lewis. 1991. Methods for dietary fiber, neutral detergent fiber, non-starch polysaccharides in relation to animal nutrition. Symposium: carbohydrate methodology, metabolism and nutritional implications in dairy cattle. J. Dairy Sci. 74:3583-3597.

Voelker, J. A., and M. S. Allen. 2003a. Pelleted beet pulp substituted for high-moisture corn: 1. Effects on feed intake, chewing behavior, and milk production of lactating dairy cows. J. Dairy Sci. 86:3542-3552.

Voelker, J. A., and M. S. Allen. 2003b. Pelleted beet pulp substituted for high-moisture corn: 2. Effects on digestion and ruminal digestion kinetics in lactating dairy cows. J. Dairy Sci. 86:3553-3561.

Voelker, J. A., and M. S. Allen. 2003c. Pelleted beet pulp substituted for high-moisture corn: 3. Effects on ruminal fermentation, $\mathrm{pH}$, and microbial protein efficiency in lactating dairy cows. J. Dairy Sci. 86:3562-3570.

Wildman, E. E., G. M. Jones, P. E. Wagner, R. L. Bowman, H. F. Troutt Jr., and T. N. Lesch. 1982. A dairy cow body condition scoring system and its relationship to selected production characteristics. J. Dairy Sci. 65:495-501.

Zanton, G. I., and A. J. Heinrichs. 2009. Digestion and nitrogen utilization in dairy heifers limit-fed a low or high forage ration at four levels of nitrogen intake. J. Dairy Sci. 92:2078-2094.

Zervas, S., and R. T. Zijlstra. 2002. Effects of dietary protein and fermentable fiber on nitrogen excretion patterns and plasma urea in grower pigs. J. Anim. Sci. 80:3247-3256. 